\title{
Australian Journal of

\section{Adaptability to varying water levels and responsiveness to NPK fertilizer in yellow velvetleaf plant (Limnocharis flava)}

\author{
Benyamin Lakitan $^{1,2^{*}}$, Hibiki Iwanaga ${ }^{3}$, Kartika Kartika ${ }^{4}$, Haris Kriswantoro ${ }^{4,5}$, Jun-Ichi Sakagami ${ }^{3}$ \\ ${ }^{1}$ College of Agriculture, Universitas Sriwijaya, Inderalaya 30662, Indonesia \\ ${ }^{2}$ Research Center for Sub-optimal Lands (PUR-PLSO), Universitas Sriwijaya, Palembang 30139, Indonesia \\ ${ }^{3}$ Faculty of Agriculture, Kagoshima University, Kagoshima 890-0065, Japan \\ ${ }^{4}$ Graduate School, Universitas Sriwijaya, Palembang 30139, Indonesia \\ ${ }^{5}$ Faculty of Agriculture, Universitas Palembang, Palembang 30139, Indonesia
}

*Corresponding author: blakitan60@unsri.ac.id

\begin{abstract}
Yellow velvetleaf (Limnocharis flava (L.) Buchenau) is an edible plant commonly found at rice fields in tropical riparian wetlands. At present, young leaves and flower buds of $L$. flava are commonly gathered from rice field during off- growing season. This plant is rarely cultivated. Research was conducted for evaluating $L$. flava response to (1) different water regimes, i.e. flooding, water saturated soil, and shallow water table, for mirroring water behavior at riparian ecosystem; and (2) NPK application rates up to 6 $\mathrm{g} /$ plant. Pots used do not have bottom drainage hole; instead four side holes were drilled on each pot at height matching to water level treatments. Primary growth traits, leaf growth analysis, and chlorophyll concentration index were measured for evaluating adaptability of the velvetleaf plant to varying water levels and responsiveness to NPK fertilizer. Results of this research indicated that L. flava was well-adapted to all water regimes varied from $3 \mathrm{~cm}$ below to $3 \mathrm{~cm}$ above soil surface but it grew better under flooded condition at depth of $3 \mathrm{~cm}$ during vegetative growth stage. The L. flava positively responded to NPK fertilizer application at rate of $6.0 \mathrm{~g} /$ plant, both during vegetative and reproductive growth stages. Increase in leaf area was driven by leaf water content but the increase in leaf area was followed by decrease in specific leaf weight.
\end{abstract}

Keywords: aquatic vegetable; domestication; flooding; riparian wetland; indigenous knowledge; marginal land; noxious weed; shallow water table; smallholder farmer; tropical wetland.

Abbreviations: DAS_days after sowing; L_leaf length; LA_leaf area; LDW-leaf dry weight; LFW_leaf fresh weight; LW_length $\times$ width; LWC_leaf water content; NPK_nitrogen phosphorus potassium; SLA_specific leaf area; SLW_specific leaf weight; TLA_total leaf area; W_leaf width.

\section{Introduction}

Limnocharis flava has been considered as a noxious weed in paddy field since both plants share similar soil and climate preferences, i.e. tropical and subtropical riparian wetlands. They compete for nutrients in rhizosphere and light in aerial space. L. flava particularly propagates via its seeds; a single plant produces about one million seeds within a year (Seneviratne et al., 2004). Rice is annual while L. flava is perennial plant; therefore, the later can occupy the wetlands at any time of the year, except during very dry soil condition. In the United States, L. flava has been included in lists of noxious weed in 46 states and has been classified as a prohibited aquatic plant in Florida (USDA, 2018).

There was not much agronomic study on cultivation of $L$. flava (Santosa et al., 2015). Most of the studies have positioned L. flava as noxious weed (Abhilash et al., 2008; Brooks et al., 2008; Gilal et al., 2016) or as heavy metal accumulator plant in soil bioremediation studies (Abhilash et al., 2009; Anning et al., 2013; Marrugo-Negrete et al., 2017).
In Southeast Asia countries, some aquatic plants, including $L$. flava and Ipomoea aquatica have long been known as edible vegetables and consumed by local communities, such as in Indonesia (Santosa et al., 2015), Vietnam (Ogle et al., 2001), and some other countries. Nowadays, they have been sold not only at traditional markets but also at franchised grocery stores.

Consumable parts of L. flava are young unfolded (juvenile) leaf blade including its petiole and immature inflorescence at flower-bud stage with its peduncle. L. flava contains comparable crude fat and crude fiber contents but lower crude protein content than other leafy vegetables do. Additionally, the edible parts of $L$. flava provide good sources of minerals such as potassium, calcium, magnesium and zinc (Saupi et al., 2009) and $\beta$-carotene (Ogle et al., 2001).

Harvesting is performed by cutting leaf petiole and flower peduncle at basal position. On average, L. flava plant 
produces new leaf in every 3 to 4 days. At reproductive growth stage, the plant produces an inflorescence after producing every 3 to 4 leaves. For maintaining plant growth, young leaf is harvested alternately at $1: 1$ or 1:2 ratios. All young inflorescences (flower bud and its peduncle) are harvested. Removal of reproductive organ as a stronger sink will induce vegetative growth (Anuradha and Bishnoi, 2017; Lucas and Liu, 2017); therefore, more leaves are produced. Considering leaf and inflorescence are the economic organs of L. flava, this study was focused on growth and development of these two organs.

Raising economic value of $L$. flava and its nutrition contents makes this plant as a promising vegetable in tropical riparian wetlands. Despite the economic prospect, at present, most of L. flava sold in traditional markets are gathered from naturally grow, non-cultivated $L$. flava at paddy field (Ogle et al., 2001; Santosa et al., 2015). Only few local farmers cultivate $L$. flava and they did not apply any fertilizer to the plants.

As aquatic plants, L. flava falls into the type of emerged plants, rooted in the bottom ground; but have most of their leaf-blades and inflorescences positioned above water surface. As emerged type, L. flava may not be able to survive under fully submersion condition. It can survive high flooding condition as long as at least part or some of its leaves protrude above water surface. L. flava grows optimally under waterlogging condition (all soil pores are filled with water) or under shallow soil water table condition (partially water-saturated rhizosphere). However, there was no study had been conducted for comparing effects of three different water regimes on vegetative and reproductive growth of L. flava.

Objectives of this study are to evaluate adaptability of $L$. flava to varying water regimes and its response to NPK fertilizer application. At present, cropping intensity at tropical riparian wetlands is very low (Lakitan et al., 2018a); therefore, benefits of this study includes increasing insight on cultivation of the velvetleaf plant as promising vegetable for increasing cropping intensity at the tropical riparian wetlands.

\section{Results}

\section{Leaf growth analysis and shoot partition}

LFW was significantly affected by water regime and NPK application rate but these two treatments did not affect LDW. The highest LFW was found in plants treated with water level at $3 \mathrm{~cm}$ above surface of growing substrate $(\mathrm{W}+3)$ and NPK application rate applied at $6 \mathrm{~g}$ per plant (F6). LWC significantly increased at higher NPK rate (F6) but was not affected significantly by water level treatment (Table 1 ). There was trend that LWC increased at higher water level and NPK application rate.

LA was significantly higher at $W+3$ and F6. The LA strongly correlated with L, W, and LW (Figure 1). This strong correlations verified accuracy of LA measurement using automated digital image analysis developed by Easlon and Bloom (2014). Furthermore, increase in LA was driven by increase in LWC (Figure 2).

SLW and SLA were not affected significantly by water regimes; however, SLA of F6 was significantly higher than unfertilized control (FO)(Table 1). This confirmed that plants fertilized with $6 \mathrm{~g}$ NPK produced larger but thinner leaves. Moreover, negative correlation was found between LA and SLW (Figure 2).

Water regimes did not affect fresh and dry weights of all components of shoot, i.e. leaf blade, petiole, and inflorescence. The treatment also did not affect TLA and total number of leaves per plant. In contrary, NPK rates significantly affected fresh weights of leaf blade and inflorescence, dry weights of petiole and inflorescence, TLA, and total number of leaves per plant (Table 2).

\section{Effects on SPAD value and reproductive organs}

SPAD values measured during vegetative and reproductive growth stages in L. flava were not significantly affected by both water level and NPK rate treatments, except at 67 DAS (Table 3). The 67 DAS is equivalent to 11 days after NPK application. Similar pattern was observed on effects of water level and NPK rate during reproductive growth stage in $L$. flava plants. Reproductive growth stage was started at 67 DAS, as marked by visible development of the first inflorescence.

Water regime did not significantly affect plant age at time of the first flower bud was developed and the first flower was blooming. The water regimes also did not influence total flower per plant, fruit/flower ratio, and total inflorescence per plant. In contrary, the NPK application rate significantly affected all parameters observed during reproductive growth stage, except total flower per plant (Table 4).

\section{Discussion}

\section{Shallow flooding increases leaf fresh weight and leaf area} but not dry weight

LFW was significantly higher under flooded condition $(\mathrm{W}+3)$ than the other water regime treatments (Table 1), indicating that water uptake by roots and transport to leaf was enhanced under such condition. Water movement was driven by water potential gradient (Ghezzehei and Albalasmeh, 2015), from high to low water potential. Water potential is determined by four components, i.e. osmosis, pressure, gravity, and matrix, but most of researches in crop science were focused on osmotic and pressure components (Schumann et al., 2014). In term of water movement, soilplant-atmosphere was a continuum (García-Tejera et al., 2017; Trautz et al., 2017), water in soil is absorbed by plant roots, transported to leaf, and released to atmosphere. Higher water uptake in W+3 plants is associated with higher pressure potential component enforced by layer of floodwater above soil surface, hence above the root zone. As an aquatic plant, roots of $L$. flava function normally under fully water saturated soil condition. Presence of aerenchyma in roots, provides sufficient oxygen for root aerobic metabolism. Ranawakage et al. (2013) observed that L. flava showed morphological adaptations to different water regimes and root biomass significantly increased in flooded conditions. This is clear advantage of cultivating L. flava over terrestrial vegetable crops which, at most, can tolerate shallow water table at $15 \mathrm{~cm}$ below soil surface or deeper 
Table 1. Leaf growth parameters as affected by water level and NPK fertilizer application rate in velvetleaf plants.

\begin{tabular}{|c|c|c|c|c|c|c|}
\hline Treatment & LFW (g) & LDW (g) & LWC (\%) & LA $\left(\mathrm{cm}^{2}\right)^{2}$ & SLW $\left(\mathrm{mg} \cdot \mathrm{cm}^{-2}\right)$ & $\operatorname{SLA}\left(\mathrm{cm}^{2} \cdot \mathrm{g}^{-1}\right)$ \\
\hline \multicolumn{7}{|c|}{ Water level (cm) } \\
\hline+3 & $6.260+1.526 a$ & $0.610+0.210$ & $89.695+4.152$ & $200.719+41.581 a$ & $3.166+1.215$ & $355.11+119.233$ \\
\hline 0 & $5.422+0.981 b$ & $0.576+0.150$ & $89.080+3.565$ & $172.879+27.592 b$ & $3.416+1.101$ & $320.87+101.953$ \\
\hline-3 & $5.200+1.156 b$ & $0.636+0.150$ & $87.027+4.757$ & $173.367+34.448 b$ & $3.853+1.343$ & $291.77+107.877$ \\
\hline Significance & * & ns & ns & * & ns & ns \\
\hline \multicolumn{7}{|c|}{ NPK rate (g/plant) } \\
\hline 0 & $4.813+0.692 c$ & $0.608+0.133$ & $87.139+3.294 b$ & $161.948+22.266 b$ & $3.826+0.998$ & $277.876+66.875 b$ \\
\hline 3 & $5.546+1.049 b$ & $0.627+0.217$ & $88.292+4.329 a b$ & $180.763+33.562 b$ & $3.584+1.320$ & $316.072+117.874 \mathrm{ab}$ \\
\hline 6 & $6.523+1.473 a$ & $0.587+0.158$ & $90.372+4.633 a$ & $204.253+40.608 a$ & $3.025+1.285$ & $373.799+122.988 a$ \\
\hline Significance & $* *$ & ns & * & $* *$ & ns & * \\
\hline
\end{tabular}

Table 2. Fresh and dry weights of shoot components, total leaf area, and leaves per plant as affected by water level and NPK application at rate of 6 gram per plant in velvetleaf plants.

\begin{tabular}{|c|c|c|c|c|c|c|c|c|}
\hline \multirow[b]{2}{*}{ Treatment } & \multicolumn{3}{|c|}{ Fresh weight (g) } & \multicolumn{3}{|c|}{ Dry weight (g) } & \multirow{2}{*}{ TLA $\left(\mathrm{cm}^{2}\right)$} & \multirow[t]{2}{*}{ Total leaves /plant } \\
\hline & Leaf & Petiole & Inflorescence & Leaf & Petiole & Inflorescence & & \\
\hline \multicolumn{9}{|c|}{ Water level $(\mathrm{cm})$} \\
\hline+3 & 25.191 & 62.630 & 29.453 & 2.575 & 4.940 & 2.641 & 782.900 & 7.222 \\
\hline 0 & 30.189 & 75.890 & 38.892 & 3.033 & 5.537 & 3.304 & 912.200 & 7.222 \\
\hline-3 & 26.776 & 66.320 & 39.847 & 2.775 & 4.632 & 3.330 & 814.400 & 6.555 \\
\hline Significance & ns & ns & ns & ns & ns & ns & ns & ns \\
\hline $\mathrm{CV}$ & 25.889 & 23.319 & 31.612 & 26.154 & 20.23 & 32.598 & 23.635 & 15.793 \\
\hline \multicolumn{9}{|c|}{ NPK rate (g/plant) } \\
\hline 0 & $22.526 \mathrm{~b}$ & 58.739 & $42.923 \mathrm{a}$ & 2.421 & $4.085 \mathrm{~b}$ & $3.907 \mathrm{a}$ & $710.180 \mathrm{~b}$ & $6.222 \mathrm{~b}$ \\
\hline 3 & $31.756 \mathrm{a}$ & 70.857 & $26.609 \mathrm{~b}$ & 3.241 & $5.522 \mathrm{a}$ & $2.090 \mathrm{~b}$ & $982.570 \mathrm{a}$ & $7.667 \mathrm{a}$ \\
\hline 6 & $27.874 \mathrm{ab}$ & 75.248 & $38.660 \mathrm{a}$ & 2.720 & $5.503 \mathrm{a}$ & $3.277 \mathrm{a}$ & $816.760 a b$ & $7.111 \mathrm{ab}$ \\
\hline Significance & * & ns & * & ns & $* *$ & $* *$ & * & * \\
\hline $\mathrm{CV}$ & 25.889 & 23.319 & 31.612 & 26.154 & 20.23 & 32.598 & 23.635 & 15.793 \\
\hline
\end{tabular}

Table 3. SPAD value was not affected by water level and only increased on 11 days after NPK application at rate of 6 gram per plant in velvetleaf plants.

\begin{tabular}{|c|c|c|c|c|c|c|c|}
\hline \multirow{2}{*}{ Treatment } & \multicolumn{7}{|c|}{ Plant age } \\
\hline & $51 \mathrm{DAS}^{2}$ & $56 \mathrm{DAS}^{\mathrm{y}}$ & 60 DAS & $67 \mathrm{DAS}^{x}$ & 73 DAS & 78 DAS & $83 \mathrm{DAS}$ \\
\hline Water level $(\mathrm{cm})$ & SPAD Value & & & & & & \\
\hline+3 & 39.667 & 41.167 & 41.822 & 39.900 & 33.911 & 34.856 & 44.144 \\
\hline 0 & 40.511 & 41.822 & 42.233 & 41.556 & 31.689 & 36.222 & 44.167 \\
\hline-3 & 39.144 & 39.900 & 41.178 & 39.120 & 32.900 & 35.378 & 44.444 \\
\hline Significance & ns & ns & ns & ns & ns & ns & Ns \\
\hline $\mathrm{CV}$ & 3.191 & 3.51 & 5.864 & 7.692 & 9.324 & 4.684 & 6.863 \\
\hline NPK rate (g/plant) & SPAD Value & & & & & & \\
\hline 0 & 39.889 & 41.133 & 40.600 & $37.867 \mathrm{~b}$ & 32.456 & 36.377 & 44.189 \\
\hline 3 & 39.567 & 40.822 & 41.744 & $40.189 a b$ & 32.711 & 35.100 & 44.267 \\
\hline 6 & 39.867 & 40.933 & 42.889 & $42.522 \mathrm{a}$ & 33.333 & 34.978 & 44.300 \\
\hline Significance & ns & ns & ns & * & ns & ns & Ns \\
\hline $\mathrm{CV}$ & 3.191 & 3.51 & 5.864 & 7.692 & 9.324 & 4.684 & 6.863 \\
\hline
\end{tabular}



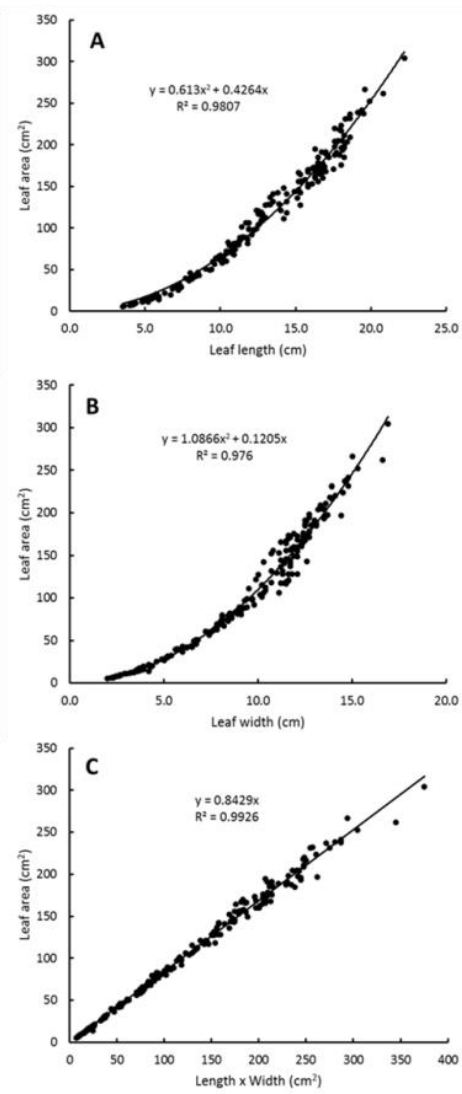

Fig 1. Correlation between leaf length (A), width (B), and length $\mathrm{x}$ width (C) with measured leaf area of Limnocharis flava. Leaf area measurements were carried out using automated digital image analysis developed by Easlon and Bloom (2014).
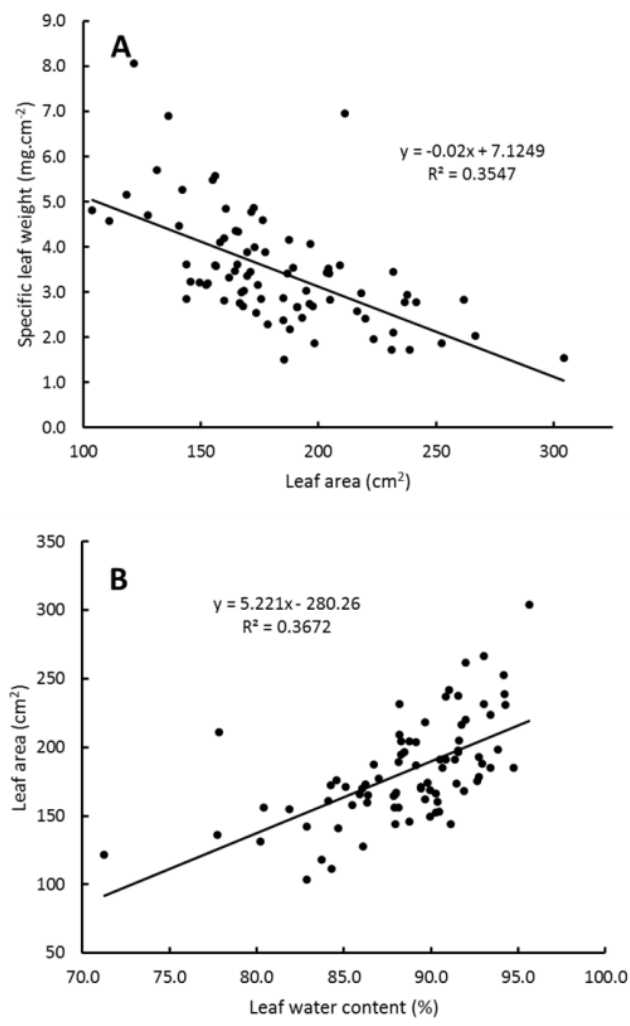

Fig 2. Leaf area negatively correlated with specific leaf weight (A) but leaf area was directly influenced by leaf water content (B). 
Table 4. Effects of water level and NPK application at rate on flower and fruit development in velvetleaf plants.

\begin{tabular}{|c|c|c|c|c|c|}
\hline Treatment & First flower bud [DAS] & First flower bloom [DAS] & $\begin{array}{l}\text { Total } \\
\text { flower/plant }\end{array}$ & Fruit/flower ratio & $\begin{array}{l}\text { Total } \\
\text { inflorescence } \\
\text { /plant }\end{array}$ \\
\hline \multicolumn{6}{|c|}{ Water level $(\mathrm{cm})$} \\
\hline+3 & 67.856 & 71.778 & 10.556 & 0.956 & 1.756 \\
\hline 0 & 68.144 & 71.878 & 11.744 & 0.956 & 1.889 \\
\hline-3 & 67.856 & 72.111 & 11.811 & 0.944 & 1.922 \\
\hline Significance & ns & ns & ns & ns & ns \\
\hline $\mathrm{CV}$ & 3.271 & 2.871 & 23.535 & 6.065 & 19.472 \\
\hline \multicolumn{6}{|c|}{ NPK rate (g/plant) } \\
\hline 0 & $64.622 \mathrm{c}$ & $68.956 \mathrm{c}$ & 12.033 & $0.944 a b$ & 2.000 \\
\hline 3 & 70.967 a & 74.678 a & 10.856 & $0.911 b$ & 1.667 \\
\hline 6 & $68.267 \mathrm{~b}$ & $72.133 b$ & 11.222 & $1.000 \mathrm{a}$ & 1.900 \\
\hline Significance & $* *$ & $* *$ & ns & $*$ & ns \\
\hline $\mathrm{CV}$ & 3.271 & 2.871 & 23.535 & 6.065 & 19.472 \\
\hline
\end{tabular}

(Lakitan et al., 2018b), but absolutely have no chance to survive under prolonged water-saturated soil and flooding conditions.

Increase in LFW in the $W+3$ plants was followed by moderate increase in LWC but significant increase in LA (Table 1). There are two possible explanations. Firstly, only fraction of water taken up by roots is transported all the way to leaf, and secondly, water transported to leaf increased internal hydrolic pressure that causing leaf expansion (Devi et al., 2015; Meihana et al., 2017; Widuri et al., 2017) and subsequently increases LA. Reversely, the increase of LA diminishes the pressure and neutralizes LWC, reflected in moderate increase of LWC.

Despite having larger $L A$, the $W+3$ plants did not have significantly higher LDW, implying that leaf of the $W+3$ plants were larger but thinner compared to leaves of W0 and W-3 plants. LWC, SLA, and SLW were also not significantly influenced by water level (Table 1). Water levels varied from $3 \mathrm{~cm}$ below to $3 \mathrm{~cm}$ above soil surface only positively affected water-related parameters but did not affect carbon fixation. Rate of photosynthesis decreased if plants are exposed to drought stress (Osakabe et al., 2014; Zandalinas et al., 2018) or hypoxic conditions (Nada et al., 2015; Pedersen et al., 2017). Yamauchi et al. (2018) explained that water-saturated soils were anoxic (lack of oxygen), so that roots of poorly adapted species suffered from oxygen deficiency condition whereas well-adapted wetland species thrived. Since $L$. flava has plenty aerenchyma in its roots and petioles; therefore, it receives adequate internal oxygen supply.

\section{NPK increases plant water status and also dry weight of petiole and inflorescence}

Higher NPK application rates (F6) increased LFW, LWC, LA, and SLA (Table 1). This hints a sequential effects of NPK fertilizer to observed parameters. Empirically, in this study, higher NPK rate was associated with increase in LWC. Kumar et al. (2017) confirmed that increase in NPK fertigation rate significantly increased relative LWC and Jeelani et al. (2017) reported that NPK application through fertigation significantly increased NPK uptake. Increase in LWC subsequently increased internal hydrolic pressure at cell level which collectively causing leaf expansion (Meihana et al., 2017; Widuri et al., 2017); thus, increased LA.
Empirically, LWC positively correlated with LA (Figure 3). In this study, however, LA increase did not follow by increase in LDW; therefore, SLA consequently increases. Increase in LWC directly associated with increase in LFW.

Water level varied from $3 \mathrm{~cm}$ above to $3 \mathrm{~cm}$ below soil surface showed indifferent effect on fresh and dry weights of all components of shoot, i.e. leaf blade, petiole, and inflorescence. Water level also did not affect TLA and total number of leaves per plant. On the other hand, NPK application rate affected fresh weights of leaf blade and inflorescence, dry weights of petiole and inflorescence, TLA, and total number of leaves per plant (Table 2). It is interesting to note that the highest fresh and dry weights amongst shoot components was the petiole. Petiole of $L$. flava is spongy but it is very long and large. Fortunately, petiole is an edible part of L. flava in addition to young unfolded leaf blade, flower buds, and peduncle (Saupi et al., 2009).

\section{NPK application only affects SPAD value for short period}

No significant effect of both water level and NPK rate on SPAD value during vegetative and reproductive growth stages, except at 67 DAS (Table 3 ) or equivalently at 11 days after NPK application. This significant effect indicated that $L$. flava is responsive to nitrogen supplied through the NPK fertilizer but the respond was only for short period of time. SPAD value has been commonly used for estimating leaf nitrogen content (Rorie et al., 2011; Vigneau et al., 2011).

Water level treatment did not significantly affect development of reproductive organs of $L$. flava. All traits related to development of reproductive organ, including time of the first flower bud developed, time of the first flower to blossom, total number of flower per inflorescence, fruit/flower ratio, and total inflorescence per plant were not affected by water regime applied. In contrary, NPK application treatment significantly affected all traits observed during reproductive growth stage, except total flower per plant (Table 4).

\section{Materials and Methods}

This pot experiment was conducted at an off-campus research facility at Jakabaring $\left(104^{\circ} 46^{\prime} 44^{\prime \prime} \mathrm{E} ; 3^{\circ} 01^{\prime} 35^{\prime \prime} \mathrm{S}\right)$, Palembang, Indonesia from early November 2017 to end of 
January 2018. Timely prepared seedlings of Limnocharis flava, a promising green vegetable at tropical wetlands, was immediately transplanted as second season crop after rice harvesting. Growing substrate used was previously grown with rice as an effort to simulate probable scenario for increasing cropping intensity under field condition at riparian wetland.

\section{Seedlings preparation}

Since L. flava is not commonly cultivated, some preliminary experiments were performed for figuring out the most effective procedure for cultivating the plant. In traditional cultivation practice, local farmers collect L. flava wild seedlings and replant the seedlings on their designated plot. In this traditional procedure, sizes and probably ages of seedlings are widely variable. Also, this traditional practice is only suitable for household-size cultivation. Results of our preliminary trials proved that L. flava can be cultivated using their seeds to produce more than one hundred of relatively uniform seedlings from a fruit. The fruits are spherical, 1-2 $\mathrm{cm}$ in diameter. Each fruit consists of 12 to 18 segments and each individual segment functions as seed sack, contains about 10 to 20 tiny seeds. Seed diameter is not more than 1 $\mathrm{mm}$. Matured seed is indicated by their black seed coat.

Growing substrate used was previously used for rice cultivation. The substrate was placed in $25-\mathrm{cm}$ diameter pots and flooded with water. Floodwater was about $2-\mathrm{cm}$ height above surface of the substrate. Mature fruits of $L$. flava were dropped to the water. On the following day, the fruit split into segments. The segments containing seeds were submerged in water. It required a few days up to a week before seeds were germinated, upon which floodwater was let to recede due to evaporation. Within a week, roots of the young seedlings have to be in direct contact with and able to penetrate into soft and muddy substrate in order for the seedlings to continuously grow. Nutrients provided by the tiny seed of $L$. flava depleted within those short period of time. The young seedlings eventually died within two weeks if they float in water without direct contact with the substrate.

\section{Cultivation practices and data collection}

Relatively uniform 81 seedlings were selected out of more than 500 seedlings. Each individual seedling of $L$. flava at age of 35 days after sowing (DAS) was transplanted to a $25-\mathrm{cm}$ diameter pot containing substrate previously grown with rice. Since the seeds were not directly planted on soil, the first day of sowing was referred to the day of fruits were dropped to floodwater in the pots.

The water-level treatment was started at 51 DAS. It was more than 2 weeks after transplanting; therefore, the plants have been well recovered from transplanting effects. Pots used for water-level treatments were drilled to make four side holes spaced equally at 90 degrees; positioned at $3 \mathrm{~cm}$ above $(\mathrm{W}+3)$, level at $(\mathrm{W} 0)$, and at $3 \mathrm{~cm}$ below $(\mathrm{W}-3)$ surface of growing substrate, respectively. These side holes were designed for controlling water level at respective settings. It should be noted that the experiment was conducted during rainy season at an outdoor facility and was not protected from rainfall. All of the plants were watered only if water surface of $W+3$ treatment fall $1 \mathrm{~cm}$ below the side holes.
Complex fertilizer comprised of nitrogen (N, 15 percent), phosphorus $\left(\mathrm{P}_{2} \mathrm{O}_{5}, 15\right.$ percent) and potassium $\left(\mathrm{K}_{2} \mathrm{O}, 15\right.$ percent), abbreviated as NPK fertilizer, was applied as additional macro nutrients source for the treated crops. The NPK fertilizer was applied at 56 DAS, during vegetative growth stage. Rates of application were $0 \mathrm{~g}$ per plant (F0) as control non-fertilized plant, $3 \mathrm{~g}$ per plant (F3), and $6 \mathrm{~g}$ per plant (F6), respectively.

Since $L$. flava is a leafy vegetable; then, more data collection was devoted to leaf growth analysis. Leaf fresh weight (LFW) and leaf dry weight (LDW) were directly measured. LFW was immediately weighted after leaf petiole was excised. LDW was weighted after the leaf blade was oven-dried at $70^{\circ} \mathrm{C}$ for 48 hours. Leaf water content (LWC), specific leaf weight (SLW), and specific leaf area (SLA) were calculated based on measured LFW, LDW, and leaf area (LA)(Meihana et al., 2017; Widuri et al., 2017). LA was measured using an automated digital image analysis (Easlon and Bloom, 2014). Measured LA was verified by correlating it with measured leaf length (L), leaf width (W), and calculated imaginary rectangular of LW (Lakitan et al., 2017).

Leaf chlorophyll concentration index $(\mathrm{CCl})$ was proxied by SPAD value, measured using Konica-Minolta Chlorophyll Meter SPAD-502Plus. The $\mathrm{CCls}$ were measured during vegetative and reproductive growth stages; also, prior to and after NPK fertilizer application.

Fresh and dry weights of shoot were partitioned into leaf, petiole, and inflorescence weights at 88 DAS, marking the end of experiment. Total leaf area per plant (TLA) is sum of LA measured for all leaves in each plant. Total number of leaves per plants was also counted.

Data collected during reproductive growth stage included plant ages at time of the first flower bud was visually recognizable, day of the first flower was blooming, total number of flowers per plant, fruit/flower ratio, and total number of inflorescences per plant.

\section{Statistical analysis}

The experiment was arranged in a split plot design. Waterlevel treatment was assigned as the main plot and NPK fertilizer application rate was as the split plot. Eighty one pots were used to accommodate 3 water-level treatments, 3 NPK-application-rate treatments, 3 replications, and each replication consisted of 3 sample plants. Calculated F-value generated from the analysis of variance (ANOVA) was compared with value of $F$-table at $p<0.05$ and $p<0.01$ for determining its significant level. The least significant difference (LSD) test was executed for justifying significant differences between treatment levels or rates. Correlation between two theoretically related parameters was done for evaluating general trend and interrelation between two parameters or influence of a parameter to another. Inferences of the results were laid on physio-morphological process in growing plant.

\section{Conclusion}

Yellow velvetleaf ( $L$. flava) exhibited its ability to grow under shallow water table to moderate depth of flooding conditions; however its ability to withstand fully submerged and drought conditions have to be evaluated. During vegetative growth stage, L.flava grew better under flooded 
condition, i.e. flooding at 3-cm depth above soil surface; however, during reproductive growth stage, development of flower and fruit did not differ significantly at water regime range between $3 \mathrm{~cm}$ below to $3 \mathrm{~cm}$ above soil surface. The $L$. flava responded to NPK fertilizer application at rate of 6.0 $\mathrm{g} /$ plant, both during vegetative and reproductive growth stages. Based on results of this study, cultivation of L. flava can be recommended for vegetable production at riparian wetlands after rice has been harvested. Moreover, application of NPK fertilizer will be beneficial in L. flava cultivation.

\section{Acknowledgements}

We would like to express our gratitude to unanimous reviewers for their comments and suggestions and to editorin-chief and staffs of this journal for their superb supports. This research was supported by Penelitian Unggulan Profesi Unviversitas Sriwijaya, grant No. 0570/UN9/PP/2017.

\section{References}

Abhilash PC, Pandey VC, Srivastava P, Rakesh PS, Chandran S, Singh N, Thomas AP (2009) Phytofiltration of cadmium from water by Limnocharis flava (L.) Buchenau grown in free-floating culture system. J Hazard Mater. 170(2-3): 791-797.

Abhilash PC, Singh N, Sylas VP, Kumar BA, Mathew JC, Satheesh R, Thomas AP (2008) Eco-distribution mapping of invasive weed Limnocharis flava (L.) Buchenau using geographical information system: implications for containment and integrated weed management for ecosystem conservation. Taiwania. 53(1): 30-41.

Anning AK, Korsah PE, Addo-Fordjour P (2013) Phytoremediation of wastewater with Limnocharis flava, Thalia geniculata and Typha latifolia in constructed wetlands. Int J Phytoremed. 15(5): 452-464.

Anuradha RK, Bishnoi C (2017) Assimilate partitioning and distribution in fruit crops: A review. J Pharmacogn Phytochem. 6(3): 479-484.

Brooks SJ, Panetta FD, Galway KE (2008) Progress towards the eradication of mikania vine (Mikania micrantha) and limnocharis (Limnocharis flava) in northern Australia. Invas Plant Sci and Manage. 1(3): 296-303.

Devi MJ, Taliercio EW, Sinclair TR (2015) Leaf expansion of soybean subjected to high and low atmospheric vapour pressure deficits. J Exp Bot. 66(7): 1845-1850.

Easlon HM, Bloom AJ (2014) Easy leaf area: Automated digital image analysis for rapid and accurate measurement of leaf area. Appl Plant Sci. 2(7): 1400033.

García-Tejera O, López-Bernal Á, Testi L, Villalobos FJ (2017) A soil-plant-atmosphere continuum (SPAC) model for simulating tree transpiration with a soil multicompartment solution. Plant Soil. 412(1-2): 215-233.

Ghezzehei TA, Albalasmeh AA (2015) Spatial distribution of rhizodeposits provides built-in water potential gradient in the rhizosphere. Ecol Model. 298:53-63.

Gilal AA, Muhamad R, Omar D, Aziz A, Azwady N, Gnanasegaram M (2016) Foes can be friends: Laboratory trials on invasive apple snails, Pomacea spp. Preference to invasive weed, Limnocharis flava (L.) Buchenau compared to rice, Oryza sativa L. Pak J Zool. 48(3): 673-679.
Jeelani J, Katoch KK, Sanjeev KS, Gupta RK (2017) Effect of varying drip irrigation levels and different methods of NPK fertilizer application on soil water dynamics, water use efficiency and yield of broccoli (Brassica oleracea L. var. italica) in wet temperate zone of Himachal Pradesh. Int J Pure App Biosci. 5(1): 210-220.

Kumar J, Kapoor R, Sandal SK, Sharma SK, Saroch K (2017) Effect of drip irrigation and NPK fertigation on soil-plant water, productivity, fertilizer expense efficiency and nutrient uptake of capsicum (Capsicum annuum L,.) in an acid Alfisol. Indian J Soil Conserv. 45(1): 105-111.

Lakitan B, Hadi B, Herlinda S, Siaga E, Widuri LI, Kartika K, Lindiana L, Yunindyawati Y, Meihana M (2018a) Recognizing farmers' practices and constraints for intensifying rice production at Riparian Wetlands in Indonesia. NJAS-Wageningen J Life Sci. 85: 10-20

Lakitan B, Kadir S, Wijaya A, Susilawati (2018b) Tolerance of common bean (Phaseolus vulgaris L.) to different durations of simulated shallow water table condition. Aust J Crop Sci. 12(4): 661-668.

Lakitan B, Widuri LI, Meihana M (2017) Simplifying procedure for a non-destructive, inexpensive, yet accurate trifoliate leaf area estimation in snap bean (Phaseolus vulgaris). J Appl Hort. 19(1): 15-21

Lucas WJ, Liu CM (2017) The plant vascular system II: From resource allocation, inter-organ communication and defense, to evolution of the monocot cambium. J Integr Plant Biol. 59(6): 354-355.

Marrugo-Negrete J, Enamorado-Montes G, DurangoHernández J, Pinedo-Hernández J, Díez S (2017) Removal of mercury from gold mine effluents using Limnocharis flava in constructed wetlands. Chemosphere. 167: 188192.

Meihana M, Lakitan B, Susilawati MU, Widuri LI, Kartika K, Siaga E, Kriswantoro $H$ (2017) Steady shallow water table did not decrease leaf expansion rate, specific leaf weight, and specific leaf water content in tomato plants. Aust J Crop Sci. 11(12): 1635-1641.

Nada RM, Khedr AHA, Serag MS, El-Nagar NA (2015) Growth, photosynthesis and stress-inducible genes of Phragmites australis (Cav.) Trin. ex Steudel from different habitats. Aquat Bot. 124: 54-62.

Ogle M, Dao H, Mulokozi G, Hambraeus BL (2001) Micronutrient composition and nutritional importance of gathered vegetables in Vietnam. Int J Food Sci and Nutr. 52(6): 485-499.

Osakabe Y, Osakabe K, Shinozaki K, Tran LSP (2014) Response of plants to water stress. Front Plant Sci. 5: 86.

Pedersen O, Perata P, Voesenek LA (2017) Flooding and low oxygen responses in plants. Funct Plant Biol. 44(9): iii-vi.

Ranawakage VP, Ellawala KC, Chaminda GT (2013) Preliminary study on the influence of water level on the growth and morphology of Limnocharis flava (L.) Buchenau. Int J Limnol 49(4): 249-254.

Rorie RL, Purcell LC, Mozaffari M, Karcher DE, King CA, Marsh MC, Longer DE (2011) Association of "greenness" in corn with yield and leaf nitrogen concentration. Agron J. 103(2): 529-535.

Santosa E, Prawati U, Mine Y, Sugiyama, N (2015) Agronomy, utilization and economics of indigenous vegetables in West Java, Indonesia. J Hort Indones. 6(3): 125-134. 
Saupi N, Zakaria MH, Bujang JS (2009) Analytic chemical composition and mineral content of yellow velvetleaf (Limnocharis flava L. Buchenau)'s edible parts. J Appl. Sci. 9(16): 2969-2974.

Schumann C, Schlegel HJ, Grimm E, Knoche M, Lang A (2014) Water potential and its components in developing sweet cherry. J Amer Soc for Hort Sci. 139(4): 349-355.

Seneviratne KACN, Wijesundara DSA (2004) Limnocharis flava (L.) Buchenau (Alismataceae)-a little known and troublesome weed in Andaman Islands. Curr. Sci. 87(2): 140-141.

Trautz AC, Illangasekare TH, Rodriguez-Iturbe I, Heck K, Helmig R (2017) Development of an experimental approach to study coupled soil-plant-atmosphere processes using plant analogs. Water Resour Res. 53(4): 3319-3340.

USDA. 2018. The plants database, NRCS-US Departement of Agriculture. https://plants.usda.gov/java/invasiveOne.
Vigneau N, Ecarnot M, Rabatel G, Roumet P (2011) Potential of field hyperspectral imaging as a nondestructive method to assess leaf nitrogen content in wheat. Field Crop Res. 122(1): 25-31.

Widuri LI, Lakitan B, Hasmeda M, Sodikin E, Wijaya A, Meihana M, Kartika K, Siaga E (2017) Relative leaf expansion rate and other leaf-related indicators for detection of drought stress in chili pepper (Capsicum annuum L.). Aust J Crop Sci. 11(12): 1617-1625

Yamauchi T, Colmer TD, Pedersen O, Nakazono M (2018) Regulation of root traits for internal aeration and tolerance to soil waterlogging-flooding stress. Plant Physiol. 176(2): 1118-1130.

Zandalinas SI, Mittler R, Balfagón D, Arbona V, GómezCadenas A (2018) Plant adaptations to the combination of drought and high temperatures. Physiol Plantarum. 162(1): 2-12. 